\title{
Characterization of peripartum cardiomyopathy by cardiovascular magnetic resonance imaging
}

\author{
Arash Haghikia1*, Philipp Röntgen ${ }^{1}$, Jens Vogel-Claussen², Denise Hilfiker-Kleiner', Johann Bauersachs ${ }^{1}$ \\ From 18th Annual SCMR Scientific Sessions \\ Nice, France. 4-7 February 2015
}

\section{Background}

Peripartum Cardiomyopathy (PPCM) is a potentially life threatening disease and the major cause of acute heart failure in the peripartum period. While many aspects of its clinical profiles have been frequently reported, functional analysis, in particular of the right ventricle, and tissue characterization by cardiovascular magnetic resonance (CMR) imaging have been only sporadically described. The aim of the present study was to analyze pathological alterations found in CMR imaging of patients newly diagnosed with PPCM.

\section{Methods}

This was a multicenter study enrolling 34 patients with confirmed PPCM who underwent CMR imaging at the time of diagnosis.

\section{Results}

Cine imaging of PPCM patients showed moderate to severe reduction of systolic left ventricular (LV) function (mean LVEF: $29.7 \pm 12.8 \%$ ). In $35 \%$ of the patients right ventricular (RV) systolic function was also reduced with a mean RVEF of $42.9 \pm 13.9 \%$. Dilatation of the LV was observed in $91 \%$ (mean LV-EDV/BSA $128.5 \pm 32.1 \mathrm{ml} / \mathrm{m}^{2}$ ) and dilatation of the RV was present in $24 \%$ (mean RVEDV/BSA $87.4 \pm 18.5 \mathrm{ml} / \mathrm{m}^{2}$ ) of the patients. Focal nonischemic late gadolinium enhancement (LGE) was visible in $71 \%$ and regional wall motion abnormalities were evident in $88 \%$ of the patients. LGE and wall motion abnormalities were predominantly located in the anteroseptal and basal to midventricular segments.

\section{Conclusions}

Beside LV systolic dysfunction, RV dysfunction and dilatation are frequently observed in PPCM patients at the

${ }^{1}$ Cardiology and Angiology, Hannover Medical School, Hannover, Germany Full list of author information is available at the end of the article time of diagnosis. The presence of LGE suggests focal damage of myocardial tissue. A distinct pattern of LV wall motion abnormalities is evident in most PPCM patients. The present study may help to establish a set of CMR criteria suitable for diagnosis in patients with suspected PPCM and contribute to our understanding of this diesease.

\section{Funding}

This study was supported by the German Research Foundation (DFG), the German Federal Ministry of Education and Research (BMBF) and the Cluster of Excellence "Regenerative Biology to Recontructive Therapy" (Rebirth).

\section{Authors' details}

${ }^{1}$ Cardiology and Angiology, Hannover Medical School, Hannover, Germany. ${ }^{2}$ Radiology, Hannover Medical School, Hannover, Germany.

Published: 3 February 2015

doi:10.1186/1532-429X-17-S1-Q46

Cite this article as: Haghikia et al:: Characterization of peripartum cardiomyopathy by cardiovascular magnetic resonance imaging. Journal of Cardiovascular Magnetic Resonance 2015 17(Suppl 1):Q46.

Submit your next manuscript to BioMed Central and take full advantage of:

- Convenient online submission

- Thorough peer review

- No space constraints or color figure charges

- Immediate publication on acceptance

- Inclusion in PubMed, CAS, Scopus and Google Scholar

- Research which is freely available for redistribution 